\title{
Class Acts
}


The publisher gratefully acknowledges the generous contribution to this book provided by the Frederick W. Hilles Publication Fund of Yale University. 


\section{Class Acts}

S E R V I C E A N D I N E Q U A L I T Y

I N L U X U R Y H O T E L S

\section{Rachel Sherman}

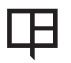

UNIVERSity OF CALIFORNA PRES

Berkeley Los Angeles London 
University of California Press, one of the most distinguished university presses in the United States, enriches lives around the world by advancing scholarship in the humanities, social sciences, and natural sciences. Its activities are supported by the UC Press Foundation and by philanthropic contributions from individuals and institutions.

For more information, visit www.ucpress.edu.

Parts of chapter 4 are reprinted by permission of Sage Publications Ltd. from Rachel Sherman, "Producing the Superior Self: Strategic Comparison and Symbolic Boundaries among Luxury Hotel Workers," Ethnography 6 (2): 131-58, copyright ( $\odot$ International Society of Adaptive Behavior, 2006. Excerpt from MAID IN MANHATTAN appears courtesy of Revolution Studios Distribution and Sony Pictures Entertainment. Excerpt from NINOTCHKA granted courtesy of Warner Bros.

Entertainment Inc.

University of California Press

Berkeley and Los Angeles, California

University of California Press, Ltd.

London, England

(C) 2007 by Rachel Sherman

Library of Congress Cataloging-in-Publication Data

Sherman, Rachel, 1970-.

Class acts : service and inequality in luxury hotels / Rachel Sherman. p. $\mathrm{cm}$.

Includes bibliographical references and index.

ISBN-13: 978-0-520-24781-9 (cloth : alk. paper)

ISBN-10: 0-520-24781-7 (cloth : alk. paper)

ISBN-13: 978-o-520-24782-6 (pbk. : alk. paper)

ISBN-10: 0-520-24782-5 (pbk. : alk. paper)

1. Hospitality industry-Customer services-United States.

2. Hotels-United States-Management. 3. Luxuries-Social aspects-United States. 4. Social classes-United States. I. Title.

TX911.3.C8S54 2006

647.94068 -dc22

2006003726

Manufactured in the United States of America

$\begin{array}{lllllllll}15 & 14 & 13 & 12 & 11 & 10 & 09 & 08 & 07\end{array}$

$\begin{array}{llllllllll}10 & 9 & 8 & 7 & 6 & 5 & 4 & 3 & 2 & 1\end{array}$

This book is printed on New Leaf EcoBook 50, a 100\% recycled fiber of which $50 \%$ is de-inked post-consumer waste, processed chlorine-free. EcoBook 50 is acid-free and meets the minimum requirements of ANSI/ASTM D5634-O1 (Permanence of Paper). 
For my parents 
